\title{
LEGAL ASPECTS OF FOREIGN INVESTMENT IN YUGOSLAVIA
}

\author{
Mirodrag Surijasovic*
}

The first law permitting foreign capital investment in the Yugoslav economy was enacted on July 27, 1967. Since then Yugoslav firms have concluded forty-two capital investment contracts with foreign firms. ${ }^{1}$ Three stages of foreign capital investment are discernible. During the first stage, which lasted from the entering of the Law of July 27 , I967 until the beginning of $\mathrm{rg69}$, foreign firms established initial business contacts with Yugoslav firms, explored general conditions under which they could invest their capital in Yugoslav projects, and asked for detailed explanations of the provisions of the Law. During this preparatory stage, only seven investment contracts were made.

The second stage, January I969 to November 1970, ended when a very serious situation in the economy of Yugoslavia resulted in the imposition of special stabilization measures. This period was characterized by the hesitation of foreign investors. Nevertheless, during this time a relatively large number of contracts, twenty-three, were concluded.

The third stage, which began with the introduction of the stabilization program and continues to the present, has brought only twelve new arrangements of this kind. However, this does not mean that the interest of foreign capital in new investment projects has dwindled or disappeared; on the contrary, it is perhaps even higher. Many of the existing arrangements represent the continuation of earlier ones, and new arrangements are contemplated. An obvious lull in the expansion of the investment activities suggests that foreign investors are waiting to see the results of our stabilization program in order to determine the effects that the economic measures and constitutional changes will have on the position of domestic firms. If the results are favorable to foreign investors they will enter into business ventures.

- Research Fellow, Institute of International Politics and Economics, Belgrade.

1 The countries with which such arrangements have been concluded are:

$\begin{array}{lclr}\text { Austria } & 2 & \text { Spain } & \text { I } \\ \text { Belgium } & \text { I } & \text { German Democratic Republic I } \\ \text { Czechoslovakia } & \text { I } & \text { Federal German Republic } & \text { Io } \\ \text { Denmark } & \text { I } & \text { Switzerland } & 3 \\ \text { United Kingdom } & 2 & \text { Sweden } & 2 \\ \text { France } & 3 & \text { International Financial } & \\ \text { Italy } & \text { I2 } & \text { Corporation (IFC) } & \text { I } \\ & \text { Total: } 40 \text { arrangements }\end{array}$

Two contracts, however, were cancelled by mutual consent.

Printing Development International, the branch of the U.S. Time-Iife Company, is shown here as a British firm since its head office is seated in London. In addition, an IFC arrangement is classified as an arrangement with Italian firms since IFC granted eight million dollars to be invested in Cruena Zastava of Kragujevac. However, no IFC contract could be classed as an American contract since IFC is an international organization, although it is a private company with a seat in Washington. 
Furthermore, slack investment has not been caused solely by internal Yugoslav processes. It is also the result of economic difficulties occurring in other countries and in the world market, particularly by the crisis in the international monetary system.

New elements have been introduced into the foreign capital investment regime, making it more favorable for foreign investors. For example, constitutional amendments have been adopted which strengthen the position and the economic power of unified labor and provide for foreign capital investment. They supplement and amend the Law on Resources and Assets of the Economic Organizations enacted on July 28, effective August 13 , I97. ${ }^{2}$ The following discussion of the rights of foreign investors should provide a basis for understanding the dynamics of capital investment in Yugoslavia.

JoInt INVESTMENTS IN a Yugoslav ENTERPRISE

A foreigner is not allowed to establish a firm in Yugoslavia which represents his capital alone. Neither is he allowed to simply invest in association with a Yugoslav partner. The only form of investment open to a foreign entrepreneur is a contract with a Yugoslav partner establishing a joint venture through which he contributes his capital to a domestic enterprise. Thus, the enterprise retains complete Yugoslav nationality.

\section{A. The Joint Investment Contract}

In practice, the joint undertaking of the foreign investor and his Yugoslav partner does not result in a joint company, that is, joint ownership over the company as an institution in which both partners invest their capital. There are no shares of stock documenting joint ownership.

The original Law on Resources and Assets of the Economic Organizations created the framework for lasting capital investment by foreign legal and physical persons in domestic economic or other organizations. The adjective "lasting" describes a trading company established for an unlimited period of time. Actually, the first arrangements were concluded for a period of only three to five years. Due to this and based on the analogy to the contracts on long-term productional cooperation, the authors of the legal act changed the notion of "lasting investment" into "long-term investment." The problem of time was ultimately resolved in the Law on Resources and Assets of the Economic Organizations. According to article 2 of the Law, contracts for the investment of foreign capital in a domestic working organization are, as a rule, of long-term nature. However, the Law permits contracts to provide for investment of capital for a predetermined period of time, although this period must not be shorter than is necessary for realization of the objectives of the planned cooperation.

\footnotetext{
${ }^{2}$ Yugoslaw Laws, No. $34 / 7$.
} 
The original text of the Law did not contain provisions on the right of breaking the contract. Thus it was normally accepted and confirmed by practice that this matter had been left up to the parties of the contract. The parties were free to include or omit a clause on termination of the contract, including the right of its unilateral cancellation. The majority of authors were of the opinion that if the contract did not contain a termination clause it could be cancelled unilaterally after a one-year period or after a longer period if a cancellation period was provided. Disputes concerning mutual rights for compensation or damages were solved according to the contract or the general provisions and regulations.

Such a clear situation was clouded by changes and amendments introduced in the Law. The Law now recognizes a distinction between cancellation by mutual consent and unilateral cancellation. In the first case, the contract cannot be cancelled before the end of its term. However, cancellation may occur before the end of the term if there are financial losses in two consecutive years or if there are bad business results within any one-year period which fall so far below the planned level that they justify cancellation. In the case of unilateral cancellation, the cancellation of the contract will be justified if one of the parties does not fulfill his obligations under the contract. Either party can cancel the contract.

\section{B. Acquired Rights}

Until the amendment of the Law on Resources and Assets in July 197r, Yugoslav legislation did not provide protection for acquired rights. This new concept was clearly designed to further encourage investments. Today, the Law guarantees that should the Law on Foreign Capital Investments change after registration of the contract, new provisions shall be applied to such contract on the condition that they are more favorable to the parties. In other words, if during the life of the contract the law which was in force at the moment of its making changes, the parties may choose the law they want to apply to their contract. If they deem the provisions of the law more convenient for their business, they can reexamine specific stipulations in the contract and change it in accordance with the provisions of the new law. Conversely, if they find the former law more favorable to their business, they need not make any changes and the contract's stipulations are still valid and the provisions of the former law are in force until the end of the term of the contract.

\section{Types of Investments}

Foreign capital can be invested in an existing Yugoslav enterprise, an existing or future organizational unit of a Yugoslav enterprise, or a future enterprise. In the third case it will also be a Yugoslav enterprise if established by a domestic partner on the basis of the contract concluded with a foreign investor. The new enterprise first must be established in law and in fact, and it must begin its corporate life on the basis of capital brought in by the Yugoslav partner. Only then may 
it accept the foreign funding as a deposit. Eventually it receives an additional deposit by a domestic partner-the founder of the enterprise.

In Yugoslav practice all three of the above mentioned types of investment are used. The first type (Crvena Zastava, Idrija) and the third type of investment (Energoinvest, Progresinvest) are more frequent than the second type, and it can be said that foreigners are mostly investing in existing or future enterprises set up by their Yugoslav partners.

\section{Liability to Third Persons: Bearing of Losses}

Questions of third-party liability are received against the background of provisions dealing with the limits on liability. It is important to consider the origin of the liability and to determine if it involves debts from joint ventures only or also debts of the Yugoslav partner created outside the joint venture. The solution of the problem will depend, therefore, on the type of investment and any additional agreements between the domestic and foreign partners.

When investment is made in a domestic enterprise as a whole, the enterprise is fully liable for its obligations to third persons. Liabilities of the foreign partner are determined by the contract and do not exceed the value of his deposit. Similar solutions are applied in compensation for losses. In this type of investment the deposit of the Yugoslav partner is his business fund for the enterprise as a whole. Joint undertakings and the undertakings of the enterprise of the foreign capital are placed in the same category. In such a case there is no difference between debts incurred in connection with the joint venture or obligations of the enterprise created before the contract on joint investment. Therefore, all debts will be joint debts and all the obligations will be joint obligations. In general, the enterprise is liable for all obligations to the extent of all its assets and resources, including those of both its native and its foreign partners. The foreign investor may protect his capital from earlier obligations only if the contract includes a protective clause in his favor.

In the second type of investment identified above, independent organizational units should be distinguished from units "with other types of self-management rights." Among the first organizational units there may be units having the characteristics of a physical person as well as units without those characteristics. An independent organizational unit with the status of a legal entity has full business capacity and controls its own resources. Its obligations and liabilities are covered by the main enterprise up to the level of the assets owned by such a unit, if the contract does not include liability of the main enterprise over that limit. In practice, a foreign investor participates in the liabilities of the joint venture up to the level of his own deposit. No contract may exclude foreign capital from the assets of the joint venture in case of execution or insolvency.

The debts of the main enterprise incurred independently of the joint venture cannot be settled from the assets of the venture unless otherwise provided in the contract. In order to protect the joint venture from such liability, it will be enough 
to avoid including in a contract a clause that assumes liability for the obligations of the main enterprise. However, even when the contract clearly states that debts of the main enterprise, incurred outside the business of the joint venture (regardless of when they were made), are not payable from invested capital, this does not mean that the creditors are completely helpless. They will first try to settle their claims from Yugoslav assets of the joint venture. If such are not sufficient, debts could be settled from the enterprise's share in the unit's profits.

The above analysis also applies to independent units without legal entity status. There is a general insulation of assets even though they do not have independent business capacity and can neither independently earn profits nor distribute assets on their own. Most of the contracts covering this type of investment do not include provisions conferring on the organizational unit (in which foreign capital is invested) liability for losses of the main enterprise and other units.

Investment in an organzational unit "with the other type of self-managing rights" may put a foreign partner into the position of those foreign partners who are investing their capital on the basis of the first type of investment since the resources of the unit are not segregated from other assets of the enterprise. Because they invest their capital in the entire enterprise, the problem of liability to third parties is resolved by analogy to the first type of investment.

Finally, when investing in a new enterprise to be created in the future, liability to the third parties should be defined by a contract. The contract should contain a clause on the amount of each partner's liability and his share in losses.

\section{II}

\section{The Nature and Vaiue of the Foreign Deposit}

As a rule, foreign capital may be invested in all types of business activities except banking, insurance, domestic transportation, trade, communal and similar services, and social programs. Investment in scientific-research projects is permitted.

The invested foreign capital may be in the form of equipment, machines, raw material, cash, technology, industrial property, know-how, or services. Very often a foreigner invests his capital in the form of cash and in kind. The interested parties set the value of non-cash deposits and record the value in the contract. It often happens that a foreign partner contributes patents and technical information to the project and offers technical services but not as a part of his deposits. In such a case, if such patents are not offered free of charge, he retains the right to royalties apart from his normal share in the profit derived from his deposit. The Law on Resources and Assets of the Economic Organizations provides that the share of domestic and foreign resources invested in a Yugoslav enterprise, or one of its organizational units, cannot be greater than forty-nine per cent foreign to fifty-one per cent Yugoslav. In other words, the value of foreign investment must not exceed the value of domestic investment nor shall it be equal to it. Therefore, the Law 
has determined a maximum but not a minimum under which the foreign deposit is not applicable.

The changes and amendments to the Law of Resources and Assets, dating from July $197 x$, introduce some innovations in this area. These innovations represent additional conditions which must be met if the contract is to be entered into the Register of the Federal Secretariat for Economy. The contract becomes effective only when confirmed by the higher authorities, which means the Worker's Council in Yugoslavia and the responsible ministry in market economy countries. To be registered, a contract must meet the following conditions: ( $x$ ) it must comply fully with federal laws; (2) it must ensure the rise of output, productivity, and exports; the introduction and application of modern technology, and the organization of output; and the promotion of scientific-research in a domestic economic organization; (3) it must meet the usual economic standards which provide for cooperation in international economic relations; (4) it must be established on the principle of equality; (5) it must protect security and defense interests of the country; and (6) it must ensure that a foreigner's non-cash contribution represents real value.

These conditions are supplemented by two additional principles. The first concerns the total investments of both partners and is linked with the requirement of raising of output, productivity, and exports. According to it, the contract shall not be registered if the total amount which the parties bring to the joint undertaking does not ensure such a rise. The second principle concerns only the deposit of the foreign partner; the application for registration of the contract will be rejected if the capital invested by the foreign investor is lower than 1,500,000 dinars. However, the Federal Secretary for Economy may make an exception to this rule depending on the nature and kind of joint venture proposed.

\section{III}

\section{OWNership Rights and Profits}

\section{A. Retention of Ownership Interests}

In Yugoslav legislation there is no provision which expressly determines whether a foreign investor can retain the ownership of invested assets. Since social ownership is not theoretically defined, it is advisable to approach the problem of the foreign investor's property rights from a pragmatic angle. Such an approach will give property rights to a foreign investor. The official statements, made in the Federal Assembly on the occasion of adopting the law on foreign capital investments and regulation of the foreigner's property rights in the assets contributed to a Yugoslav project, indicate that such rights do exist in the foreign investor. According to these statements, the Yugoslav provisions guarantee the integrity of a foreign investor's property. Although the word "ownership" is omitted from these provisions, it is 
clear, at least from the practical point of view, that the formulation "the integrity of their property" can be interpreted as the right of retaining ownership.

Ownership rights include the right of participation in profit, the right of transfer of profit, the right of repatriation of the deposit (property or financial capital), and the right of disposal or transfer of the interest gained through joint venture. All of these rights, except that pertaining to the repatriation of capital, were clearly defined from the very beginning. The foreign investor has the right to share in the profit only during the period in which he participates with his own resources in the joint venture. The right of repatriation was recognized by the Law on Resources and Assets of the Economic Organizations, dating from I967, as "the right to withdraw the invested property in a joint venture." But in spite of the fact that such legal language concerns only physical property, it does not challenge the right of retransfer of the financial deposit and financial countervalue invested in physical property. Such an interpretation has been confirmed by article 5 of the July, 197I, amendments to the above Law. In addition, amendment XXII (clause 4) to the Federal Constitution SFRY provides the right of organizations of unified labor to "use the property of foreign persons" if found convenient. It is further stated that "the rights of a foreign person to his property invested into an organization of unified labor in the country, could not be limited by the force of law or any other act." In this manner the foreign investor is guaranteed all his rights, paramountly the right of ownership.

Finally, Yugoslav practice in the field of joint investment justifies the above described attitude toward ownership rights. Investors from market economies who have made contracts with our firms are convinced that they have remained owners of the property which they have invested in Yugoslav firms. One could argue that a foreigner can retain title to his property only if his contract contains an explicit stipulation to this effect. The silence of the contract could mean a refusal of the recognition of ownership. In fact, however, only a small number of the contracts concluded up to this point contain explicit provisions concerning title to the invested property. In spite of this, both foreign and domestic partners behave as if ownership is in fact retained. Every year the value of foreign property is revised and part of it written off. These amounts then belong to the owner of the property (machines and equipment). Depending on the contract, these amounts may be retained on a different legal basis in the amortization fund of the enterprise as the owner's reinvestment, or they can be transferred abroad.

This practice has been confirmed by the above-mentioned provisions of article 5 of the amended Law on Resources and Assets. Thus, a positive presumption was established in favor of the foreign partner, and foreign property is presumed to remain the property of the foreign investor unless he explicitly provides otherwise.

Foreign assets, unless expressly declared to be social property, cannot be considered as such. In regard to their use, however, such assets qualify as property to which the regime of social property is applied. Thus, the workers of the domestic 
enterprise, the receiver of foreign capital, use such property and treat it as the means of production owned by the social sector; they keep it, maintain it, and pay insurance premiums on it. However, since such property is privately owned, it is separately maintained through the bookkeeping operations. Foreign property is classed as a guest capital temporarily present in the domestic enterprise. When the objective of the joint undertaking is fulfilled or the contract comes to an end, the foreigner reclaims his capital in one form or another, and it is treated as if it had never been introduced into the venture.

\section{B. Profit Evaluation and Distribution}

The Yugoslav provisions permit partners to organize and maintain a joint bookkeeping service. In practice, the profit is determined and divided in the manner used by all domestic firms. Operational costs and amortization of fixed assets are deducted from the total earnings. The rest of the profit is for distribution among the partners on the basis of their deposits. Therefore, before the foreigner is given his part of the profit, the profit has to pass through all the phases of deduction in the same manner as the profit share of the domestic partner. In this regard, however, the practice is not completely uniform. In some cases, deductions are treated as joint expenses and both partners bear them equally. In other cases, the profit share of the foreigner is not subjected to pro rata participation in the payment of expenses, for instance, or the payment of interest on the business fund. It is obvious that such arrangements are a matter of agreement between the parties to the contract.

A foreigner must pay the appropriate tax on his part of the profits in compliance with the tax law regarding profits earned by foreign persons who invest their capital in a domestic economic organization for the purpose of joint ventures. ${ }^{3}$ The basis of such taxation is the foreigner's capital contribution. The regular tax rate is thirty-five per cent, but the law also provides for tax reduction rates in cases where a foreigner reinvests more than the compulsory twenty per cent of his profits. The regulation on the compulsory twenty per cent deposit has been cancelled by article 4 of the Law Amending the Law of Resources and Assets of the Economic Organizations so that the rest of his profit, after taxes, can be transferred abroad. In this manner one large obstacle was removed to a more vigorous flow of foreign capital into Yugoslavia.

Underdeveloped republics and autonomous provinces are authorized to apply their own regulations on tax reduction rates and other benefits for those foreign partners who invest in a domestic enterprise in their territory. According to the Law passed by the Republic of Montenegro, the foreign partner will be taxed at the rate of fourteen per cent on his invested capital (instead of thirty-five per cent). However, if a foreign partner reinvests more than twenty per cent of the profit realized on his capital during one year, the tax will be further reduced by ninety

\footnotetext{
${ }^{3}$ Yugoslav Laws, No. 3I/67.
} 
per cent. If he deposits more than twenty per cent of the profit at a commercial bank in the republic for a period of at least three years, the tax will be reduced by eighty per cent. Other insufficiently developed republics (SR Bosnia and Herzegovina, SR Macedonia) and the Autonomous Region of Kosovo have not yet enacted their own regulations in this matter.

Despite the attractiveness of these reductions, they have yet to be applied to any joint production project. The adoption of regulations authorizing the reduction is a positive sign, however, and future accommodation to the foreign investor can be foreseen:

\section{IV}

\section{Management}

Unlike ordinary Yugoslav enterprises, domestic enterprises in which foreign capital has been invested have an organizational structure which includes, apart from management bodies, the joint business board. However, this board is not necessary in all cases. According to the Law on Resources and Assets, partners in a joint venture may decide ( $I$ ) to provide for an organization without the joint bodies, (2) to establish a joint business board with an advisory function only, and (3) to establish a board having decision-making power in the particular field of business activity. According to the Law on Resources and Assets the contract should include a clause on the composition, responsibilities, and method of operation of the joint business board.

Since the first two schemes do not offer the foreign investor a means to directly affect the venture, all arrangements concluded to date have been based on the third alternative. They have used joint boards with decision-making rights. Such boards are not managing organs, but are merely responsible for proper execution of the contract.

\section{A. Composition of the Business Board}

In practice the parties have always applied the principle of parity, regardless of their roles. This means that no one party could participate in a board with a greater number of representatives than the other party. As a joint body the business board does not represent a tool which checks the management. The boards are mainly composed of an odd number of members (three members, for instance) and rarely of an even number of members. Some contracts provide for two institutions, Management and the Board of Experts (Cinkarna, Celje, Unis).

\section{B. Responsibilities}

Some contracts specify only the list of duties for which the business board is responsible, leaving the functions of the Worker's Council and other managing bodies to determination by the law. In some other arrangements, the responsibility 
of the Worker's Council and that of the business board are expressly defined. In addition, the business board may submit its proposals to the Worker's Council, suggesting solutions to specific problems in the domain of its responsibilities (the work force, wages, and so on). Another arrangement, however, may include a list of matters which are the responsibility of the Worker's Council, to be decided, however, only on the board's proposal. There may also be a list of responsibilities within the exclusive jurisdiction of the business board.

The business board is responsible mainly for production and sales. In this area the expertise and experience of the foreign partner should be fully employed. All other issues, particularly those controlled by the mandatory rules of Yugoslaviastandards, distribution of the profit of the Yugoslav partner, wages, work rules, and other statutory questions which remain under the exclusive responsibility of the Worker's Council-may, by contract, and during the term of the contract, be withdrawn from its exclusive responsibility. These questions should be settled during the contract negotiation and the resolution specified in the contract. If the Worker's Council adopts the contract, it has made a final decision on it.

Another method of assigning obligations consists of including in the contract a clause which obliges the Worker's Council to consult the business board on a given problem before making its decision. If the business board, because of a disagreement, is not in a position to prepare a proposal or if its proposal is rejected by the Worker's Council, foreign investors will be offered an opportunity to withdraw from the contract if all efforts to reach agreement fail. In this manner neither side is forced to accept a decision which it considers to be harmful to its own interests.

\section{Management}

With regard to decision-making, previously concluded contracts provide for the business board to make decisions either unanimously (for instance, Top, Crvena Zastava, Cinkarna, Energoinvest, Konus) or by majority vote (Idrija, Progresinvest, Chromos, Beogradski Grafincki Zavod). Here, the simple or qualified majority of votes is required, and in such a case the vote of one representative either does or does not constitute a veto. Such an' example is Beogradski Graficki Zavod. In the case of Elecktrosrbija the negative vote does not represent a veto.

Rigid positions, disagreements, and disputes may normally occur in spite of strict distribution of responsibilities between the Worker's Council and the business board. However, experience has shown that this presents no serious impediment in their operation. In the case of disagreement the decisive factor is the opinion and judgment of experts. Sometimes, general directors are included in co-ordination of work. Arbitration can also be used, but it has been unnecessary thus far.

\section{CoNCLUSION}

The results achieved in the area of joint investments over the four-year period are relatively modest. The interest of foreign investors is less than had been ex- 
pected, even though there are some foreign capital investment projects of imposing proportions. Practice has shown that social ownership and workers' selfmanagement can co-exist with foreign private capital if the foreigners come with honest intentions, expecting reasonable profits from their investments. The condition of the foreign market probably has been the main factor affecting the interest of foreign capital in Yugoslav projects. Another negative influence is the unclear and unattractive legal regime of capital investment in Yugoslavia.

However, the current changes on the world market may encourage the investing of foreign capital in Yugoslavia. This undoubtedly will be the result of the stabilization of the Yugoslav economy which always has had its comparative advantages. Finally, the fact that legal interference has been reduced by recent amendments to the Law on Resources and Assets of the Economic Organizations will also have its effect. This is particularly true with respect to the modification of the provisions which obligated the foreign investor to reinvest twenty per cent of his after-tax profit. It also should be expected that legislation concerning foreign capital investment will be developed further, together with the development of the whole Yugoslav community. In this sense, the future foreign trade and foreign exchange regimes are expected to give new impetus to joint investment projects, especially if customs duties should become more liberal as to equipment and materials and if domestic manufacturers obtain greater rights in the use of foreign currency which they have earned. 